\title{
RISKS AND OPPORTUNITIES TO SOCIO-ECONOMIC AND ENVIRONMENTAL SUSTAINABILITY OF COASTAL CITIES: LA PAZ AND LOS CABOS, MEXICO. ANALYSIS OF BIOPHYSICAL FLOWS FROM A METABOLIC PERSPECTIVE
}

\author{
ADOLFO DE LA PEÑA-BARRON, ANTONINA IVANOVA BONCHEVA, \\ JOSÉ ANTONIO MARTÍNEZ DE LA TORRE \& ANGÉLICA MONTAÑO \\ Universidad Autónoma de Baja California Sur, México
}

\begin{abstract}
This paper presents, in terms of biophysical flows within a complex framework, the implications of existing relationships at the intersection between social and natural spheres in the coastal cities of La Paz and Los Cabos, located at the south of Baja California Peninsula, Mexico. This zone is of significant geostrategic potential in the Pacific Ocean, particularly on the west coast of the American continent. The paper analyses the metabolic dynamics of these two urban centers during the last twenty years, a period of explosive process of urbanization and demographic growth, driven mainly by a natural scenic and tourist capital. This poses major unresolved challenges in energy, water and food that becomes even greater because these two cities are located within an energetic island, and in an area vulnerable to climatic conditions; fundamentally it is a desert zone with scarce sources of drinking water.

Locally, there is no fossil fuel extraction or refinement. The electricity grid supplying these two urban centers is isolated from the mainland, and is virtually dependent on the supply of fossil fuels from outside the peninsula.

The dynamics of growth and the demand for resources and services increase every year, and these are supplied almost exclusively by sea transport and distributed through peninsular infrastructure. From a complex integrative approach, risks related to safety, quality of life, health and environmental degradation are of great concern.

The conclusions indicate that to move to less risky scenarios requires comprehensive urban planning and management from a complex perspective. Finally, the paper presents some potential transition opportunities, from this dynamic systemic view.
\end{abstract}

Keywords: biophysical flows, environmental sustainability, La Paz, Los Cabos, Mexico.

\section{INTRODUCTION AND CONTEXT}

Last year marked the 20th anniversary of the Second Conference of the United Nations (UN) for Human Settlements (HABITAT II), held in Istanbul in 1996. It is clear that during this period urban dynamics have changed, Latin America and Mexico do not escape this dynamic. This paper analyzes the transformation and the challenges of two coastal cities in Mexico: La Paz City and Cabo San Lucas City. These two cities are located in the state of Baja California Sur (BCS) in the extreme northwest of the Mexican Republic. This state represents only $3.77 \%$ of the national territory. It borders to the east with the Sea of Cortes, to the south and west with the Pacific Ocean (see Fig. 1). In the last survey of 2015, there were 763,929 inhabitants in the entity. In 1990, the total population of the state was 317,764 inhabitants [2], that is, the population of the state grew almost 2.5 times. The state of BCS has five municipalities. In the southern part of the state are located the municipalities of La Paz and Los Cabos. The annual growth rate of the population in the municipalities of La Paz $(3.0 \%)$ and Los Cabos (8.4\%) for the period 2005-2010 [2] is well above the average population growth in Mexico (1.8\%). 


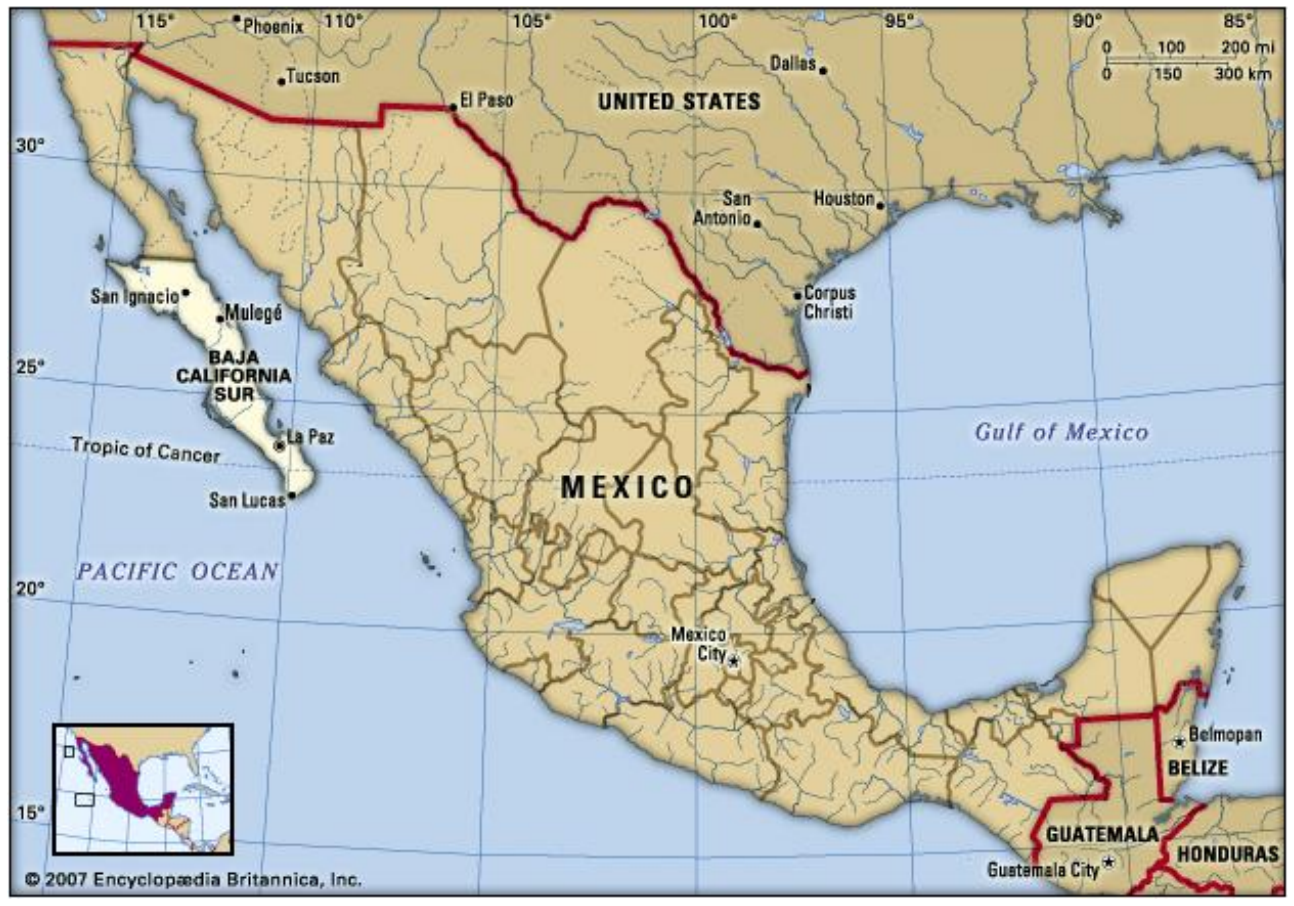

Figure 1: Location of the state of Baja California Sur, Mexico [1].

$86 \%$ of the state's population resides in urban areas. La Paz and Los Cabos account for $80 \%$ of the total. In these two municipalities are located the two coastal cities most representative of the socio-economic dynamics of the state. La Paz is the capital city of the state of BCS, bordering to the east with the Sea of Cortez. The city of Cabo San Lucas is located south of the capital city at a distance of 152 kilometers, bordering the Pacific Ocean. BCS Gross Domestic Product (GDP) in 2013 was 117,252 million Mexican pesos (6,237 million dollars), representing trade $17.9 \%$; Services linked to restaurants and hotels a total of $13.3 \%$; Real estate and rental activities $10.0 \%$ [2]. In the south of the state and more specifically in the urban area there are no surface water reserves. Practically all the water used in the urban zone comes from underground fossil water sources. In general, in BCS, the climate is dry desert, and the temperature can exceed 40 degrees Celsius in summer. In Los Cabos region the climate is warm sub-humid, exposed to the impact of tropical cyclone [3]. The state does not have the attribution to generate, exploit and/or refine fossil fuels, that's why all fuels used in urban areas are transported by sea. Between the years, 2010 and 2013 the fuel came mainly from Salina Cruz, Oaxaca. As an outstanding feature, the sulfur content in the fuel ranges up to $4 \%$, although fuel from Long Beach, California has been used to a lesser extent with much lower sulfur contents between $1.5 \%$ and $1.77 \%$ [4]. The electrical generation system in the area is isolated from the national electricity system; practically BCS is an energy island (see Fig. 2). The energy consumed in the state and in the main urban centers has to be generated, in real time. This means that the energy that is being consumed in real time, must also be delivered in real time, there are currently no energy storage systems installed in the electricity grid. The balance of electric energy reflects this in the BCS system (see Fig. 3) [5]. 


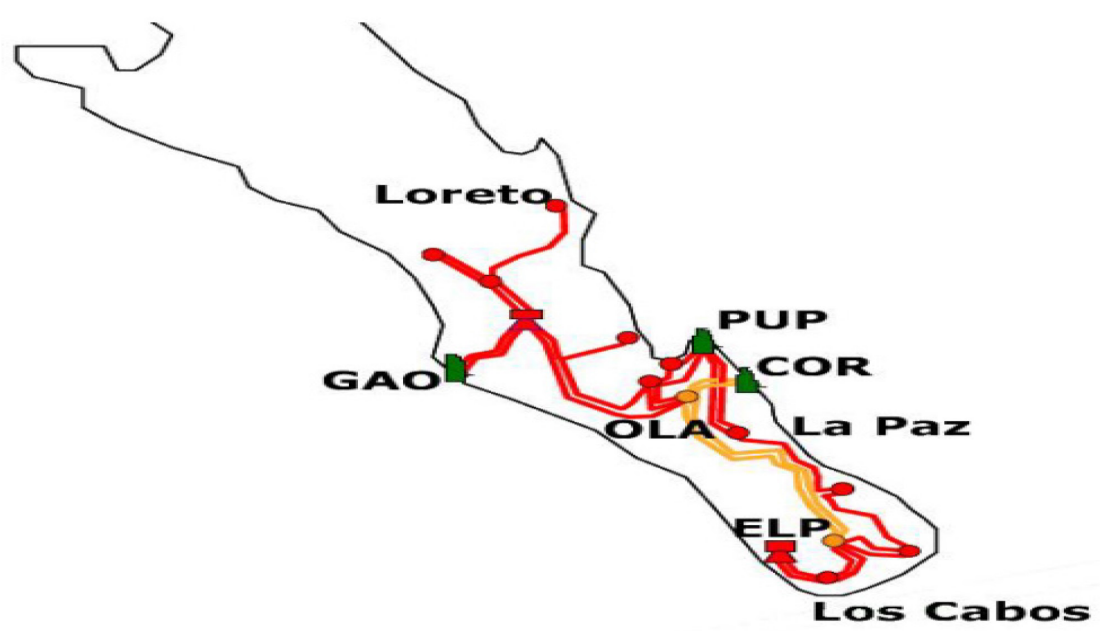

Figure 2: Electric grid in Baja California Sur [8].

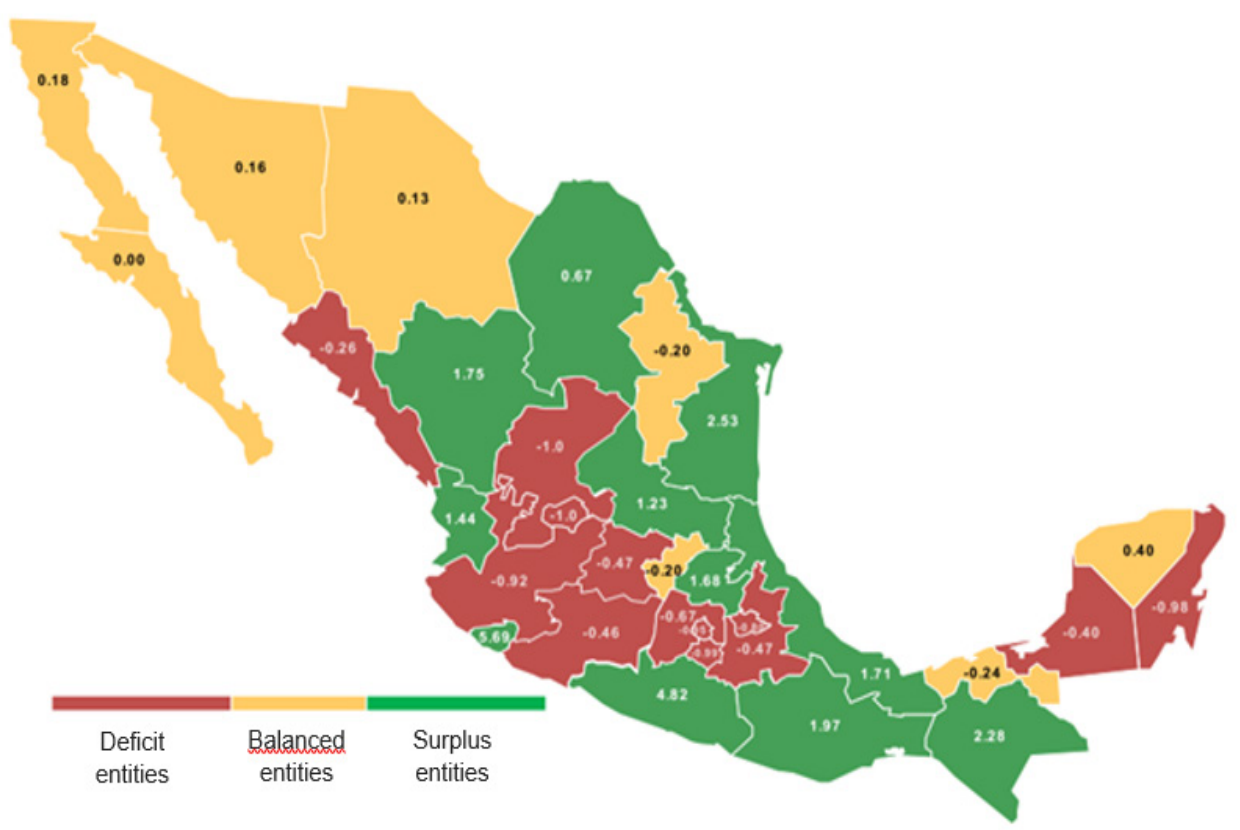

Figure 3: Balance by federal entity in Mexico [5].

The economic challenges implicit in this dynamic are also considerable. BCS has the highest growth of demand for electric power in the country. According to the Energy Secretariat (SENER) and the Federal Electricity Commission (CFE), the BCS area has increased its annual demand by approximately $40 \mathrm{MW}$. Therefore, it is necessary to install, 
every year, an additional internal combustion plant similar to the five plants that are operating in an area adjacent to the city of La Paz. As an example of the economic complexity and the energy challenges for this case, we can mention that for 2008 a five-star hotel with 300 rooms in Mexico paid around US\$ 1.2 million per year for electricity [6]. Meanwhile the cost of the last installed internal combustion plant was US\$ 107 million [7]. It is important to note that a large-scale hotel can claim up to $10 \mathrm{MW}$ of installed capacity. Thus, the opening of four hotels of this size in the area of Los Cabos would require, practically, the construction of a new plant of generation similar to those already mentioned.

It is expected that between 2016 and 2030, the average annual growth of the integrated maximum electric demand for BCS will be $5.3 \%$, this is above the national average of $3.7 \%$ [6]. This demand will be further increasing in the southern part of the state, where the city of La Paz and Cabo San Lucas are located. Puerto Pichilingue is the main commercial and industrial port of BCS. It is located within the Bay of La Paz on the shores of the Sea of Cortez 17 kilometers from the city of La Paz. Through this port enters BCS general cargo, bulk cement, liquefied petroleum gas and food. It also provides service as tourist port [9], [10]. Within the bay of the city of La Paz is located the port that bears the same name, one of the safest regions for the navigation of tourist boats in the Gulf of California [9]. By the year 2013 in this port there were 759 spaces available for boats, by 2015 this number increased to 866 spaces [2]. In this area is also located a point of discharge of fossil fuels, mainly fuel oil, diesel and gasolines, fuels that supply practically all the state of BCS.

\section{METHODOLOGY AND RESULTS}

The quantitative analysis of the research is based on the National Geostatistical Framework of the National Institute of Statistics and Geography (INEGI) [11], using the total data of the geostatistical urban areas of the two coastal cities. For energy and materials flows, existing data were used for the analyzed years. When data were not available, they were estimated by interpolation and/or equivalent per unit for the parameter analyzed. For the inventory of pollutants, the base year is 2013. La Paz has a main geostatistics area that concentrates a total of 4,811 blocks and 79,716 private houses, of which 64,500 are inhabited; $93 \%$ of the homes in this area have electricity and drainage, $91 \%$ of them have piped water, 214, 494 inhabitants live in this area (see Fig. 4). The other complementary urban area is El Centenario. It comprises a total of 389 blocks and 1,493 private homes, of which 1,140 are inhabited; $96 \%$ have electricity; $94 \%$ have piped water and $95 \%$ have drainage. The population of the two identified areas for the year 2015 totaled 218,575 inhabitants; this represents $80 \%$ of the inhabitants of the municipality. The tourist infrastructure of temporary accommodation services and food and beverage preparation for the urban area of the city of La Paz total a total of 1,583 units; Only one of them has more than 100 employees, that is, the bulk of this type of business is concentrated in small units. For the year 2014, 290 tourists visited this area, where the majority was of national origin [2]. The flow of tourists is not comparable with the dynamics of Cabo San Lucas, due to the number and size of hotels. The energy balance, in the sector of generation and consumption of electric energy, also reflects this.

Energy uses for the La Paz area are concentrated in electricity generation, transportation energy, and energy to produce heat. The generation of electrical energy, is concentrated in the two stations: Punta Prieta and Baja California Sur. For the two seasons the fuel consumption for the year 2013 was 327,918 cubic meters and 13103 cubic meters of diesel, the total generation of electric energy was $1,372,827 \mathrm{MWh}[12]$. The net power generation for the same year for the municipality of Los Cabos was 171,083 MWh, compared to the generation of La Paz is negligible. Energy use is further divided between residential and industrial uses with $37 \%$ and $46 \%$, respectively. 


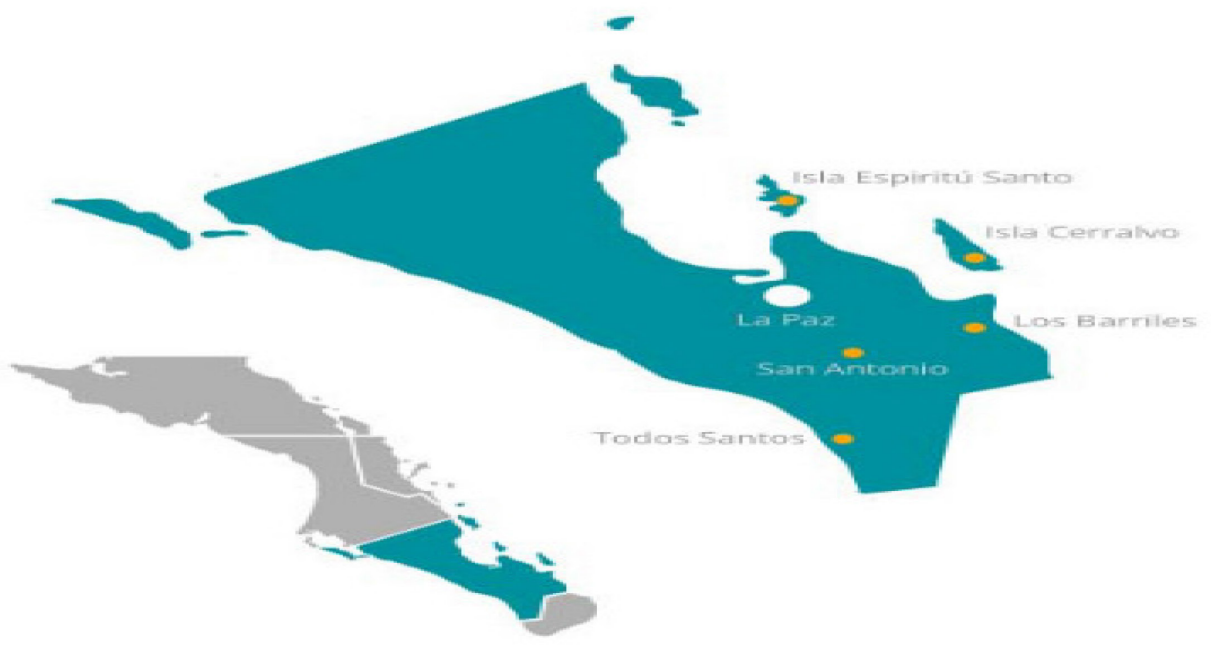

Figure 4: Location of La Paz City [15].

On the other hand, according to the Ministry of Communications and the General Directorate of Ports, the total cement flow that entered the port of Pichilingue for the year 1995 was 72,098 tons, reaching a historic high in 2007 with a total of 411,639 tons, this is an increase of a little less than 6 times. This is a year before the crisis of 1998. By 2014, the total flow of cement was 206,390 tons. In the year 1995 existed 103,851 motor vehicles in the state, for the year of 2014, the number of vehicles amounted to 422,716, thus growing 4 times. The Sustainable Urban Mobility Plan (PIMUS) for the city of La Paz reported that the motorization rate could reach 1.27 vehicles per inhabitant [13]. This could mean that in the urban area of La Paz for the year 2015 were circulating a total of almost 280,000 vehicles. It is important to note that all transportation of fuels, goods and materials is done mainly by land transportation. These arrive at the port of Pichilingue, and are distributed to the rest of the state of BCS. A bridge that surpasses the natural water channel in rainy season located in the colony October 8 is an important point of terrestrial communication between the southern part and the northern part of the city of La Paz. It is located just at the only point of exit towards the city of Cabo San Lucas, where the avenue converges with greater vehicular flow and the load unloading. At this bridge, circulate 50,000 to a little more than 70,000 vehicles a day [13]. It is no coincidence that according to INEGI, the state of BCS is the most motorized in the country [14].

The urban area of Cabo San Lucas consists of three main geostatistical points. The first of them is the one identified with the name of Cabo San Lucas that groups a total of 1,372 blocks and 66,464 inhabitants. This area has 26,972 private homes of which 20,725 are inhabited; $91 \%$ with electricity and $90 \%$ with drainage, and $85 \%$ of these homes have piped water. In this area is located the bulk of establishments of this urban area that provide tourist services, real estate services, temporary accommodation services and food preparation.

The next urban area, adjacent to the former, is Colina del Sol. It has a total of 678 blocks; 47,754 inhabitants and 16,047 private homes, of which 12,958 are inhabited; $89 \%$ with electricity, $91 \%$ with drainage and only $44 \%$ have piped water. The following geostatistical area is identified by the name of Las Palmas, adjacent to the aforementioned area. It consists of 224 blocks with 10,218 inhabitants. There are located 3,668 private homes, of which are 
inhabited 2,982. Of the total inhabited homes, $79 \%$ have electricity; $83 \%$ have drainage and $60 \%$ have piped water. These last two areas are located in the second contour of the urban containment perimeters identified by the Secretariat of Agrarian, Territorial and Urban Development (SEDATU). That is, these areas are surrounding to the location of sources of employment, services and infrastructure. The sum of the resident population in these three areas represents a little over $43 \%$ of the total population of the municipality.

In the period $2010-2013,78 \%$ of tourists who visited the state were concentrated in the municipality of Los Cabos, reaching in 2013 the total number of tourists to 1.69 million [15]. In the urban area of the city of Cabo San Lucas there are a total of 941 economic units of temporary accommodation and food and beverage preparation, this represents a little more than $50 \%$ of economic units in this area of the municipality of Los Cabos; $78 \%$ are large companies with more than 100 workers [16]. At the state level, large companies with more than 100 employees contribute $27.4 \%$ of the total production linked to this item [2].

For 2008, only the hotel sector in the municipality of Los Cabos consumed $880 \mathrm{GWh} /$ year [17], electricity delivered after discounting energy losses for the same year was $1,951 \mathrm{GWh} /$ year [18]. That is, the hotel sector was consuming $45 \%$ of the total energy delivered in the state. For the year 2013, the general conditions of consumption of electric power for this sector in the state remain constant with $46 \%$ [12].

\section{ANALYSIS OF BIOPHYSICAL FLOWS: RISKS AND OPPORTUNITIES}

The socio-economic challenges in general for coastal cities have multiple interconnection edges. These connections become more complex within a scenario characterized by extreme insular and climatic conditions, as in this case. A systemic perspective allows to tackle in holistic way the weaknesses and strengths of these urban centers. The analysis starts with requirements and metabolic flows that sustain the urban network, and therefore, the urban life in society of the inhabitants of the studied system. This view has its starting point from Wolman's [19] vision and works with "The Metabolism of Cities" [19]. This scheme

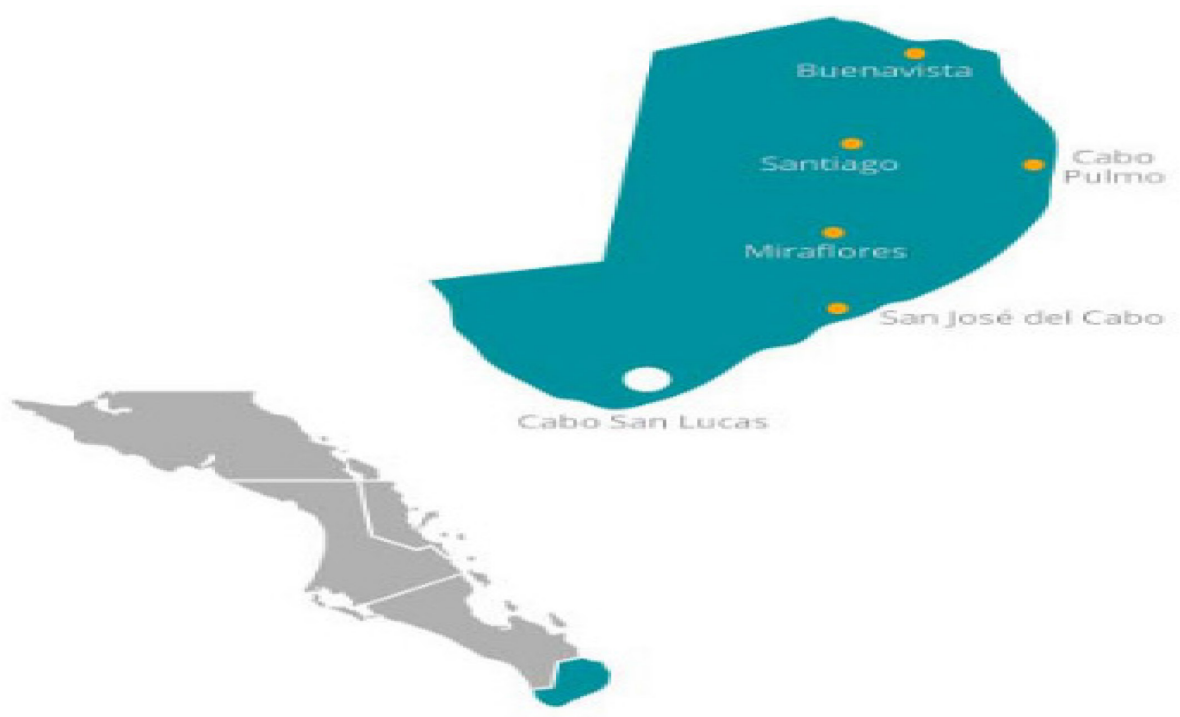

Figure 5: Location of Cabo San Lucas City [15]. 
identifies three main input and three output streams. The first three are water, food and fuels, and the second three are wastewater, solid waste and atmospheric pollutants [20]. If this complex vision is not taken into account, socio-environmental problems become more acute as demands and flows of materials and energy advance.

Due to the insular, not only geographic, but also energetic, conditions under which these two coastal cities are immersed, a space is opened for a more direct analysis between the present links between energy, climate change, air quality and socio-economic challenges. This helps us to put in context the demands for resources, infrastructure and service that could be presented in the future, as well as their negative effects.

In the first instance, the geographical location of the two coastal cities places them within a framework of vulnerability and eminent risk. The proximity to coastal areas makes them vulnerable to flooding and sea level rise. In addition, the cities exposed to the impact of tropical cyclones, for example, the case of Hurricane Odile affected the peninsula in 2014, with sustained winds of over $200 \mathrm{~km} / \mathrm{h}$ and cyclone spears of $250 \mathrm{~km} / \mathrm{h}$ [21]. It was necessary to mobilize 6,200 workers, 500 emergency power generation plants and 2, 200 working vehicles. This had an operating cost of 2,300 million pesos [22], more than US\$ 120 million. In the economic sector, the occupation of the inhabitants of the state presents a considerable bias, since a little more than $70 \%$ of the jobs are concentrated in the services sector [2]. Evidently, this is more visible in the case of Cabo San Lucas. The biggest risk in terms of infrastructure is in the domestic area, largely in the outlying areas of the city of Cabo San Lucas, similar to the infrastructure of electric power transmission, which is vulnerable to impacts of atmospheric phenomena. It is important to remember that electric machines carry out the extraction and pumping of water, so they depend on the availability of electric energy. According to the Ministry of the Interior, at the municipal level the last year of updating the atlas of risk was carried out in 2012, while for the municipality of Los Cabos this document was updated for the year 2013 [23].

According to the Energy Secretariat and the Federal Electricity Commission, the BCS area has experienced an increase in annual demand of approximately $40 \mathrm{MW}$, that is, one more internal combustion plant every year, similar to one of the five plants that are operating in the area adjacent to the city of La Paz. As an example for this case, we can consider that in 2008 a five-star hotel with 300 rooms paid around US\$ 1.2 million per year for electric energy [23]. While the cost of the last installed internal combustion plant was US\$ 107 million [7]. It is important to note that a large-scale hotel can claim up to $10 \mathrm{MW}$ of installed load, so the installation of four hotels of this size in the area of Los Cabos would require the construction of a new plant of similar generation capacity.

\section{FINAL REMARKS}

Urban planning and regulation, implementation of climate action and resilience plans, financing, social participation and monitoring of all these actions are policies and instruments that should be implemented not in the future, but today.

Opportunities exist in the development and implementation of renewable energies, as well as in enhancement of energy efficiency. Important options are the solar thermal energy sector, heat recovery in industrial processes and self-generation through cogeneration systems, small and large-scale wind systems, and photovoltaic systems. An important component of energy policies are the storage systems.

The water resource is already a fundamental issue in these two coastal cities. The new urban areas of the Cabo San Lucas, where most homes do not have piped water, present the clearest example of water scarcity. A solution already explored by the Government of Mexico through the National Institute of Nuclear Research (ININ), is the installation of a combined 
cycle plant by a nuclear reactor, an option that has a significant economic benefit and represents lower $\mathrm{CO}_{2}$ emissions compared to other generation sources. A positive element for implementation of clean energies is that in Los Cabos there are regulatory restrains on emissions.

To implement such alternative solutions in short term would be crucial for environmental and socio-economic sustainability of the development of La Paz and Los Cabos, continuity of tourism affluence and enhancement of the living standards of the population.

[1] Google Maps. 2017. Retrieved from:

\section{REFERENCES}

https://www.google.com.mx/search?q=State + of + Baja + California + Sur + in + map + of + Mexico + and + the + USA\&tbm $=\mathrm{isch} \& \mathrm{tbo}=\mathrm{u} \&$ source $=$ univ\&sa $=\mathrm{X} \& v e d=0 \mathrm{ahUKEwiHz}$ tP3p9TTAhVpr1QKHRdNBqIQ7AkIMA\&biw=2186\&bih=1171\&dpr=0.85\#imgrc $=$ PRaL40hKvQ9CsM:\&spf=306

[2] Gobierno del Estado de Baja California Sur. Información Estratégica Baja California Sur. La Paz. 2015. Retrieved from http://spyde.bcs.gob.mx/files/die/2015/ EstrategicoBCSJulio2015.pdf

[3] De La Peña-Barron, A. Metabolismo social, energía y cambio climático en el estado de Baja California Sur. Universidad Autónoma de Baja California Sur. 2017.

[4] Secretaría de Energía. Programa de desarrollo del sistema eléctrico nacionalPRODESEN 2016-2030. 2016.

[5] Rowe, L., Paredes Rubio, H.R., Reveles González, B., Chidiak, M. \& Stanley, L. Análisis de mercado para la aplicación de tecnología de energías renovables y eficiencia energética en hoteles en México, y mercado potencial para el sector financiero. Ciudad de México. 2009. Retrieved from http://energy-base.org/wpcontent/uploads/2013/11/REEEP-UNEP-CONUEE-Market-Analysis-of-RenewableEnergy-and-Energy-Efficiency-in-Hotels-in-Mexico-Spanish.pdf

[6] CFE. Informe Anual Comisión Federal de Electricidad. Ciudad de México. Comisión Federal de Electricidad. Boletín de prensa de la Comisión Federal de Electricidad. La Paz, Baja California Sur. México. 2015. Retrieved from http://saladeprensa.cfe.gob.mx/boletines/show/8216/

[7] Bermúdez, A. Energías renovables para la generación de electricidad en Baja California Sur. UABCS, La Paz, 2015.

[8] API-BCS. Administración Portuaria Integral de Baja California Sur. 2017. Retrieved from www.apibcs.com.mx

[9] Secretaria de Comunicaciones y Transportes. Sistema Portuario Nacional. 2017. Retrieved from www.sct.gob.mx/puertos-y-marina/

[10] INEGI. Marco Geoestadístico Nacional. 2017b. Retrieved from www.inegi.org.mx/geo/contenidos/geoestadistica/m_geoestadistico.aspx

[11] Bermudez-Contreras, A., Ivanova Boncheva, A., de la Peña-Barron, A., Bermudez, A., Casillas, E., Landa, P. \& Lucero, B. Inventario de emisiones para la ciudad de La Paz, Baja California Sur. La Paz, Baja California Sur. México, 2016.

[12] PIMUS. Plan integral de movilidad urbana sustentable de la ciudad de La Paz, Baja California Sur, 2014.

[13] Junta Estatal de Caminos. Conteo de aforo vehícular realizado en el puente de la colonia 8 de octubre. La Paz, Baja California Sur. México, 2014.

[14] Secretaría de Turismo. Agenda de competitividad del destino turístico de Los Cabos. Los Cabos Baja California Sur (Vol. 1). Ciudad de México. 2014. https://doi.org/10.3865/j.issn.1001-3547.2009.20.004 
[15] INEGI. DENUE - Directorio Estadístico Nacional de Unidades Económicas. 2017. Retrieved January 20, 2017, from www.beta.inegi.org.mx/app/mapa/denue/

[16] Ivanova, A., Ganster, P. \& Arizpe, O. Los Cabos prospectiva de un paraiso natural y turístico. San Diego, California: San Diego State University Press, 2012.

[17] INEGI, \& Gobierno del estado de Baja California Sur. Anuario estadístico de Baja California Sur. Aguascalientes, Aguascalientes, 2009.

[18] Wolman, A. The Metabolism of Cities. Scientific American, 1965, 213(3), 179-190.

[19] Carlo, G., Ramos, D., Campos, C. \& Rentería, P. "Cambio Climático y el Metabolismo Urbano de las Megaurbes Latinoamericanas" Climate Change and Urban Metabolism of Latin American Megacities, 2012, 2, 2-25.

[20] Bravo, C. Reseña del huracán "Odile” del Océano Pacífico (Vol. 14), 2014.

[21] Secretaría de Energía. Prospectiva del Sector Eléctrico 2015-2029, 2015, 237.

[22] SEGOB. Atlas Nacional de Riesgos. 2017. Retrieved from www.atlasnacionalderiesgos.gob.mx/

[23] Rowe, L., Paredes Rubio, H.R., Reveles González, B., Chidiak, M. \& Stanley, L. Análisis de mercado para la aplicación de tecnología de energías renovables y eficiencia energética en hoteles en México, y mercado potencial para el sector financiero. Ciudad de México. 2009. Retrieved from http://energy-base.org/wpcontent/uploads/2013/11/REEEP-UNEP-CONUEE-Market-Analysis-of-RenewableEnergy-and-Energy-Efficiency-in-Hotels-in-Mexico-Spanish.pdf 